\title{
Article \\ Él Code-Switches More Than tú y yo: New Data for the Subject Pronoun-Verb Switch Constraint
}

\author{
Kate Bellamy ${ }^{1, *(\mathbb{D})}$, Hans Stadthagen-Gonzalez ${ }^{2}$ and M. Carmen Parafita Couto ${ }^{3,4}$ (D) \\ 1 Department of Linguistics, KU Leuven, 3000 Leuven, Belgium \\ 2 Department of Psychology, University of Southern Mississippi, Long Beach, MS 39560, USA; \\ H.Stadthagen@usm.edu \\ 3 Language Variation and Textual Categorisation, Universidade de Vigo, 36310 Vigo, Spain; \\ m.parafita.couto@hum.leidenuniv.nl \\ 4 Leiden Institute for Brain and Cognition, Heritage Languages of the Netherlands Lab (HERLING), \\ Leiden University Centre for Linguistics (LUCL), 2300 RA Leiden, The Netherlands \\ * Correspondence: kate.bellamy@kuleuven.be
}

check for updates

Citation: Bellamy, Kate, Hans Stadthagen-Gonzalez, and M. Carmen Parafita Couto. 2022. Él Code-Switches More Than tú y yo: New Data for the Subject Pronoun-Verb Switch Constraint. Languages 7: 22. https://doi.org/ 10.3390/languages7010022

Academic Editor:

Bryan Koronkiewicz

Received: 9 August 2021

Accepted: 14 January 2022

Published: 28 January 2022

Publisher's Note: MDPI stays neutral with regard to jurisdictional claims in published maps and institutional affiliations.

Copyright: (C) 2022 by the authors. Licensee MDPI, Basel, Switzerland. This article is an open access article distributed under the terms and conditions of the Creative Commons Attribution (CC BY) license (https:// creativecommons.org/licenses/by/ $4.0 /)$.

\begin{abstract}
In early studies, code-switches between a subject pronoun and a finite verb were considered highly dispreferred or even impossible. However, naturalistic data from several language pairs has since highlighted that such switches are possible, although their grammaticality is constrained by the typology of the pronouns involved. In this study, we test the switching constraints postulated for subject pronouns-verbs among P'urhepecha-Spanish bilinguals $(n=12)$ from Michoacán, western Mexico. Using a two-alternative forced-choice acceptability judgement task (2AFC), we found that, contrary to expectations, switches between a third person singular pronoun and a verb were considered the most acceptable, followed by the coordinated 'you and I' second person, then the first person singular. The same order was found for both switch directions, despite third-person pronouns in P'urhepecha having a stronger typological profile. Building on the results of previous studies, we suggest that the lack of preference for a single switch direction is evidence for language-specific codeswitching patterns, as well as possible differences in productive vs. receptive language. Additionally, we highlight the probative value of judgement data, particularly those emerging from 2AFC tasks, as a means of expanding our understanding of grammaticality in code-switching.
\end{abstract}

Keywords: code-switching; subject pronoun-verb switch; P'urhepecha-Spanish bilinguals; judgement tasks

\section{Introduction}

Code-switching is a natural and commonly occurring phenomenon; it can be observed in the speech and writing of multilinguals who go back and forth between their languages in the same conversation or text (e.g., Deuchar (2012)). As the following English-Spanish examples demonstrate, code-switching happens both between (1a) and within (1b) clauses.
(1a) Sometimes I'll start a sentence in Spanish, y termino en español and I finish in Spanish

(Poplack 1980)

(1b) Estaba snowing it was

(Miccio et al. 2009)

It is generally accepted that code-switching is not a random process (cf. Labov (1971)), but is a rule-governed speech practice, indicative of high proficiency in, and active use of, both/all of a speaker's languages (e.g., Poplack (1980)). Speakers choose when, where and with whom to code-switch, and intuitively regulate the switch points. Code-switching may also facilitate language production: recent evidence suggests that habitual code-switchers have a higher global speech rate in bilingual mode (i.e., when they are code-switching) than 
when they are unilingual mode (i.e., not switching; Johns and Steuck (2021); cf. Meuter and Allport (1999)). Nonetheless, the regularities and innovations observable in code-switched speech can-and should-inform theories of (multilingual) grammar more broadly (e.g., Toribio (2017); López (2020)).

The rules governing code-switching have, to date, largely been formulated in terms of structural constraints, such as the subject pronoun-verb constraint (e.g., MacSwan (1999) for Spanish-Nahuatl; see also MacSwan (2021)). Yet these constraints are often based on data from a small number of language pairs, sometimes just (one community of) SpanishEnglish speakers. Studies focusing on the same constraint or switch site may also use different methodologies, making their results less comparable and thus the overall claims less convincing (see, e.g., Parafita Couto et al. (2021) for an overview). Moreover, there is an expanding body of evidence to indicate that code-switching patterns are also modulated by community norms (e.g., Blokzijl et al. (2017)). There is, therefore, a clear need to expand the empirical base to test existing constraints, especially with typologically varied languages. The present study contributes to this broadening of the evidence base by focusing on the subject pronoun-verb constraint in P'urhepecha-Spanish bilinguals in Michoacán, Mexico.

\subsection{Background}

According to early studies, switches between a subject pronoun and a finite verb were dispreferred or even impossible (see Lipski (1978) on Spanish-English judgements; Timm (1975) on Mexican Spanish-US English production data from California; see also Lipski (2019); van Gelderen and MacSwan (2008)). An example of such a switch can be observed in the English-Spanish example in (2a). In contrast, and as highlighted by Fuertes et al. (2016), a switch between a full lexical DP and a finite verb continues to be considered acceptable, see $(2 b)$.

(2a) *She odia los exámenes

'She hates exams'

(Fuertes et al. 2016, p. 80)

(2b) That teacher odia los exámenes

'That teacher hates exams'

(Fuertes et al. 2016, p. 80)

However, as has been the case for many proposed constraints, counter-evidence for a (near-)ban on subject pronoun-verb switches soon emerged (see Toribio (2017) for a critique of the prevailing claim and counter-claim culture in code-switching research). This evidence stems from several sources, including a spoken corpus of French-Moroccan Arabic in Morocco, compiled by Bentahila and Davies (1983), see (3a, 3b).

(3a) Moi dxlt

'I went in'

Compare French unilingual: je suis entré 'I went in'

(Bentahila and Davies 1983, p. 313)

(3b) Nta tu vas travailler

'You, you are going to work' （Adapted from Bentahila and Davies (1983, p. 313)

Compare Moroccan Arabic unilingual: nta matažiš lhna 'you don't come here'

Two noteworthy points emerge from these examples: first, the switch can go in both directions; in other words, a pronoun from French or Moroccan Arabic can be followed by a verb (and other elements) in the other language of the pair. Second, the behaviour of the two switch directions is not the same (see Deuchar (2020) for a discussion of directionality in code-switching). In (3a), the French discourse-emphatic pronoun moi 'me' combines directly with the Arabic finite verb, even though in unilingual French mode, the personal pronoun $j e$ ' $I$ ' would be used to express the subject. In contrast, in ( $3 b)$ there is doubling between the discourse-emphatic Arabic pronoun $n t a$ 'you' and the French personal pronoun $t u$ 'you' (see also the discussion of the Matrix Language Frame (MLF) model below).

On the basis of evidence such as that presented in $(3 a, 3 b)$, it has been claimed that the grammaticality of the subject pronoun-verb switch is modulated by the typology or features 
of the pronouns involved (see Cardinaletti and Starke (1999)). To this end, two approaches have been proposed to account for (un)acceptable switches: Generativism/Minimalism on the one hand, and the Matrix Language Frame model on the other.

\subsection{Generativist/Minimalist Approaches}

In reference to Spanish-English, González-Vilbazo and Koronkiewicz (2016) outline the four contexts in which a subject pronoun-verb switch is allowed:

- Coordination, e.g., tú y yo ordered ... (you and I)

- Modification, e.g., él con el pelo negro ordered ... (him with the black hair)

- Prosodic stress, e.g., pero ÉL ordered ... (HE)

- Clefts, e.g., dijo que es él que ordered ... ([she] said that it is he who)

Subject pronouns are considered to be syntactically akin to lexical DP subjects in these contexts (they are 'strong', as in example (2b)), thereby licensing the switch (see also Koronkiewicz (2020)). In MacSwan's (1999) Nahuatl-Spanish judgement data, however, switches are constrained by the person of the pronoun: a Spanish (underlined) subject pronoun followed by a Nahuatl verb is only acceptable for the third person (4a, 4b).

(4a) Él kikoas tlakemetl

\begin{tabular}{|c|c|c|}
\hline$\underline{\underline{\mathrm{El}}}$ & ø-ki-koa-s & tlake-me-tl \\
\hline$\overline{\text { he }}$ & 3S-3Os-buy-FUT & garment-PL-NSF ${ }^{1}$ \\
\hline $\begin{array}{l}\text { 'He will buy } \\
\text { clothes' }\end{array}$ & & (MacSwan 1999, p. 129) \\
\hline${ }^{*} \underline{Y o}$ nikoas tlakemetl & & \\
\hline$\underline{Y_{0}}$ & ni-k-koa-s & tlake-me-tl \\
\hline 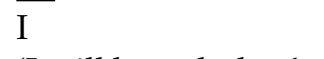 & 1S-3Os-buy-FUT & garment-PL-NSF \\
\hline
\end{tabular}

These judgements also hold when the subject pronoun is postponed to the end of the clause, as indicated in $(5 a, 5 b)$.

(5a) Kitlalia tlantikuaske nochipa él

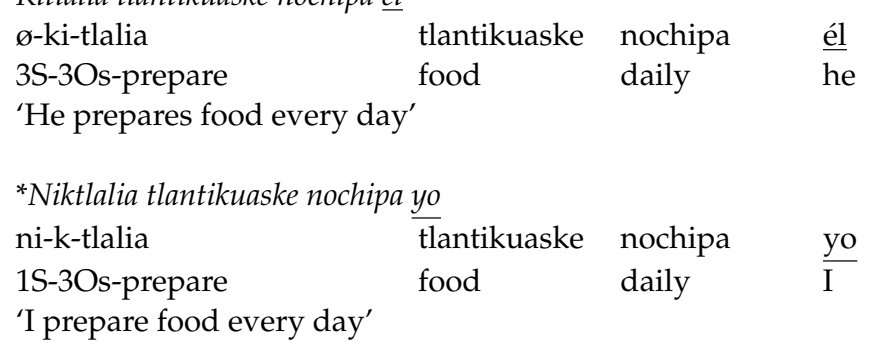

(MacSwan 1999, pp. 129-30)

The permitted switch with the third person pronoun in Spanish corresponds to the absence of overt third-person subject marking in Nahuatl (MacSwan 1999, pp. 128-29). A different picture emerges, however, when the switch is between a Nahuatl subject pronoun and a Spanish verb; here switches are degraded for the first person (marked by '?'), and unacceptable for other persons, see $(6 a, 6 b)$.

(6a) ?Ne tengo (una) casa 'I have a house'

(6b) *Te tienes (una) casa 'You have a house'

(MacSwan 1999, p. 130)

The second person is especially unacceptable due to the similarity between the Spanish te (second person singular clitic/reflexive) and Nahuatl te (second person singular subject pronoun), which are phonetically identical but syntactically behave very differently. 


\subsection{MLF Approach}

The MLF assumes an asymmetry between the languages participating in a codeswitched clause. One language- the matrix language-provides the system morphemes, that is, morphemes that do not assign thematic roles (e.g., finite verb morphology), while the other language - the embedded language-generally provides content morphemes, such as nouns, which do assign or receive thematic roles (Myers-Scotton 1993, 2002). The matrix language of a clause is identified on the basis of two principles: the Morpheme Order Principle (MOP) and the System Morpheme Principle (SMP). The MOP indicates the language that provides the word order for the clause, while the SMP indicates which language provides the system or functional morphemes, such as finite verb morphology.

In an MLF analysis, then, it is necessary to establish what kind of morphemes the personal pronouns are in a given language, namely system or content. Jake (1994) identifies four types of subject pronoun cross-linguistically (underlined and in boldface type in column two), two of which are classified as content morphemes, and two as system morphemes (see Table 1).

Table 1. Types of pronouns (in boldface and underlined) according to the MLF.

\begin{tabular}{ccc}
\hline Pronoun Type & Example (French) & Content/System Morpheme \\
\hline Discourse-emphatic & $\underline{\text { moi }, j^{\prime} \text { ai faim }}$ & Content morpheme \\
Dummy & $\underline{\text { il y a un livre sur la table }}$ & System morpheme \\
Indefinite & $\underline{\text { quelqu'un veut partir }}$ & Content morpheme \\
Personal & je veux manger & System morpheme \\
\hline
\end{tabular}

The classification of subject pronouns is language-specific but, irrespective of the language, only those that are classified as content morphemes can participate in switches with verbs (Myers-Scotton 1993; Jake 1994) In Table 1, therefore, only discourse-emphatic (as in examples in (3) and (4), above) and indefinite personal pronouns can participate in code-switches. These two types of pronoun would be considered akin to lexical DP subjects in a Minimalist analysis.

\section{Materials and Methods}

The aim of the present study is to investigate subject pronoun-finite verb codeswitching preferences among P'urhepecha-Spanish bilinguals in Mexico. P'urhepecha is a language isolate spoken in the state of Michoacán by around 125,000 people, the majority of whom are bilingual with Spanish, the main national language of education, administration, commerce, etc. (INEGI 2010). The language has been the subject of scholarly investigation since the mid-sixteenth century, when some of the earliest descriptive and lexicographic works in the Americas appeared (e.g., Gilberti [1559] 1975, Gilberti [1558] 1987). The modern era has provided only one full-length grammar (Chamoreau 2000), although shorter works, including grammar sketches (and a whole host of articles on specific topics) are also available (e.g., Foster 1969; Friedrich 1984; Capistrán Garza 2015, chp. 1; Bellamy 2018, chp. 1).

$\mathrm{P}^{\prime}$ urhepecha is a wholly suffixing, agglutinative language with extensive derivational resources, including a large set of spatial location suffixes (e.g., Friedrich 1971; Monzón 2004; Mendoza 2007). It possesses both subject pronouns and subject (and object) clitics, which may co-occur in the same clause (see (7), taken from the first author's own corpus (Bellamy forthcoming)).

(7) T'ueskiri?

$\mathrm{t}^{\prime} \mathrm{u}-\mathrm{e}-\mathrm{s}-\mathrm{ki}=$ ri

you-PRED-PERF-INTERROG = 2.SG.S

'You are?' 
Both P'urhepecha and Spanish have first, second and third person pronouns, with all three occurring in both the singular and the plural. That said, the third person pronouns are marked for different features: Spanish has a masculine/feminine distinction (él, ella 'he, she'), while the $\mathrm{P}^{\prime}$ urhepecha pronouns indicate distance and visibility in relation to the speaker ( $i$ 'this, proximal', inte 'that, distal and visible', ima 'that, distal, not visible'). Table 2 provides an overview of the two subject pronoun paradigms.

Table 2. Subject pronoun paradigms in P'urhepecha and Mexican Spanish.

\begin{tabular}{|c|c|c|c|c|c|}
\hline & P'urhepecha & Mexican Spanish & & P'urhepecha & Mexican Spanish \\
\hline 1SG & $\mathrm{ji}$ & yo & 1PL & jucha & nosotros \\
\hline 2SG & $t^{\prime} u$ & tú, usted & $2 P L$ & cha & ustedes \\
\hline 3SG & i, inte, ima & él, ella & 3PL & ts'ï, ts'ïmi, ts'ïma & ellos, ellas \\
\hline
\end{tabular}

Moreover, third person pronouns in P'urhepecha are synchronically identical to the demonstrative pronouns. Depending on the location of the person (or object) in relation to the speaker, any of the three forms can therefore be used by a P'urhepecha speaker. In (8a), the third person plural distal visible ts'imi functions as a personal pronoun, whereas in (8b), it functions as a demonstrative pronoun.

(8a) Ts'ïmi sapirhastiksï

$$
\begin{array}{ll}
\text { ts'ïmi } & \text { sapi-rha-s-ti }=\text { ksi } \\
\text { 3.PL } & \text { small-SF.PL-PERF-3.S.ASS = 1/3.S }
\end{array}
$$

'They are small.'

(8b) Ts'ïmi kurucha sapirhastiksi

$\begin{array}{lll}\text { ts'ïmi } & \text { kurucha } & \text { sapi-rha-s-ti }=\text { ksi } \\ \text { 3.PL } & \text { fish } & \text { small-SF.PL-PERF-3.S.ASS }=1 / 3 . S\end{array}$

'Those fish are small.'

Note also that the inclusion of the personal pronoun in (8a) is optional since subject person marking is present in the form of the clitic $=k s \ddot{i}$. Alternatively, the clitic could be omitted, but then the pronoun would be required to differentiate between first and third person plural, if context could not. As such, it seems that third person pronouns in P'urhepecha could be considered strong (in the Minimalist/generativist sense) or discourseemphatic and, thus, content morphemes (in the MLF sense).

\subsection{Research Questions}

On the basis of previous findings, as well as the differences between the two sets of subject pronoun systems in P'urhepecha and Spanish, two principal research questions and associated hypotheses were formulated. The first tests the Minimalist/generativist proposal that only strong or contextually lexical pronouns are acceptable in code-switches, while the second tests the MLF prediction that only content morphemes can partake in pronoun-verb switches.

RQ1: Are strong or contextually lexical pronouns, namely, coordinated pronouns (e.g., tú y yo, t'u ka ji 'you and I'), more acceptable than less lexical ones (e.g., nosotros, jucha 'we') in pronoun-verb switches?

Expectation: Coordinated pronouns are more acceptable than non-coordinated pronouns.

RQ2: Are content morphemes (e.g., P'urhepecha ima 's/he, that') more acceptable than system morphemes in switches?

Expectation: The third-person pronouns in $\mathrm{P}^{\prime}$ urhepecha may be preferred as they are also demonstratives and can be considered content morphemes, while the others (and all those in Spanish) could be considered system morphemes and, thus, dispreferred. 


\subsection{Stimuli}

Three subject pronouns were used from each language (Spanish and $\mathrm{P}^{\prime}$ urhepecha): 1SG, yo/ji ' 'I', 1PL coordinated, tú y yo/t'u ka ji 'you and I', and 3SG él/ella/ima s/he' (distal, non-visible in $\mathrm{P}^{\prime}$ urhepecha). For each pronoun we generated five sentences with the switch going from P'urhepecha to Spanish and five from Spanish to P'urhepecha. Each pair of sentences differed in the subject pronoun, which was always sentence-initial, and its verbal agreement. This gave us a total of 15 pairwise comparisons in each switch direction. Examples of such pairwise comparisons can be found in (9a-9c), where the P'urhepecha subject pronouns are underlined.

(9a) ji trabajo cada día hasta las 10

1SG vs. 3SG

ima trabaja cada día hasta las 10

'I//s/he work(s) every day until 10.'

(9b) ji corro muy lentamente

1SG vs. 1PL

t'u ka ji corremos muy lentamente

'I / / you and I run very slowly.'

(9c) ima canta canciones tradicionales

$t^{\prime} \mathrm{u}$ ka ji cantamos canciones tradicionales

'S/he//you and I sing traditional songs.'

3SG vs. 1PL

Sentences with the opposite switch direction (Spanish to P'urhepecha) take the same form, but only the subject pronoun is in Spanish (see Appendix A for a full list of the stimuli).

\subsection{Task}

Participants completed a two-alternative forced-choice acceptability judgement task (2AFC) administered through Qualtrics. In the 2AFC task participants are presented with successive pairwise comparisons of exemplars belonging to all the relevant conditions and are asked to select one preferred item from each pair. The 2AFC task has been shown to be a good method for measuring subjective judgements (Stadthagen-González et al. 2018). Comparative judgments present multiple advantages over other methods used for acceptability judgements such as Yes/No acceptability tasks and Likert-type scales (see, e.g., Párraga (2015)), including higher inter- and intra-participant reliability (Mohan 1977); higher statistical power (Sprouse 2011), and more sensitivity to contrasts between conditions (Stadthagen-González et al. 2018).

The task consisted of 30 experimental stimuli (five per condition $\times$ two switch directions), 40 fillers, and eight quality control items. For each item, participants saw two code-switched sentences and were asked to choose which sounded more natural to them. Experimental stimuli consisted of pairwise comparisons between all the relevant conditions described above, while filler items contrasted code-switched sentences with different gender-assignment strategies for nouns (the analysis of those items has been reported in (Bellamy et al. 2018). The quality control items included code-switched sentences containing an incorrect subject-verb agreement in both languages (four in $\mathrm{P}^{\prime}$ urhepecha, four in Spanish). The criterion for exclusion from the study was set at three or more incorrect answers for these quality control questions, but there was no need to exclude any participants based on this criterion. The order of presentation of items, as well as the order of each member of a pair within an item, was individually randomized for each participant. The 2AFC task was completed first, followed by a sociolinguistic questionnaire.

\subsection{Participants}

Twelve participants (six female) with an average age of 27;9 years (range $=21 ; 6-37 ; 9$, SD 5.1) took part in the experiment. All are $\mathrm{P}^{\prime}$ urhepecha-Spanish bilinguals, 11 of whom were born in Michoacán, and all were living there at the time of testing. Nine participants reported acquiring P'urhepecha from birth to two years, two from the age of four and one from 
primary school onwards. Only one participant (the same who started speaking P'urhepecha at primary school) reported learning Spanish from birth to two years and so represents the only early sequential Spanish-P'urhepecha bilingual in the sample. Of the P'urhepecha L1 speakers, two reported learning Spanish from age four or earlier, six from primary school, one from secondary school, and one as an adult. Regarding current language use, only one participant reported speaking only $\mathrm{P}^{\prime}$ urhepecha at home and with friends. Three use half-half $\mathrm{P}^{\prime}$ urhepecha and Spanish, while five use a lot of P'urhepecha and a bit of Spanish, and the final three, a lot of Spanish and a bit of P'urhepecha in the same contexts.

Participants also self-reported frequency of and attitudes towards code-switching. One participant reported using P'urhepecha and Spanish in the same sentence every day, four reported that they did so a few times a week, one once a week, two a few times a month, two less than once a month, and two stated that they never engaged in such a practice. To the statement, "people should avoid mixing P'urhepecha and Spanish in the same conversation", responses varied across the spectrum: two were totally in agreement, four in agreement, two neither agreed nor disagreed, two were in disagreement and two totally disagreed.

\section{Results}

Data from the forced-choice responses were analysed using Thurstone's (1927) analysis for comparative judgements case V. The measures resulting from Thurstone's analysis can be interpreted as values on an interval scale that represent the acceptability of the codeswitched sentences and are relative to the pattern with the lowest acceptability for each direction of switch (which is, by convention, set to 0 ). The unit of measurement along that scale is defined as the standard deviation of the distribution, so the measure itself provides information about its variability. Stadthagen-González et al. (2018) provide further details on the use of this type of analysis in code-switching research. We calculated the confidence intervals using Montag's (2006) method, which was specifically developed for paired comparison data. The $95 \%$ confidence interval for the data collected was \pm 0.15 .

Figures 1 and 2 summarise the results of our analysis for Spanish to P'urhepecha and $\mathrm{P}^{\prime}$ urhepecha to Spanish switches, respectively. For both switch directions, the third person singular pronoun is preferred well above the other two options. Second in preference is the coordinated 'you and I' pronoun, followed by the first person singular, again for both switch directions. In the case of a Spanish subject pronoun and a P'urhepecha verb, the differences between each rank (i.e., each pronoun) are all significant (see Figure 1).

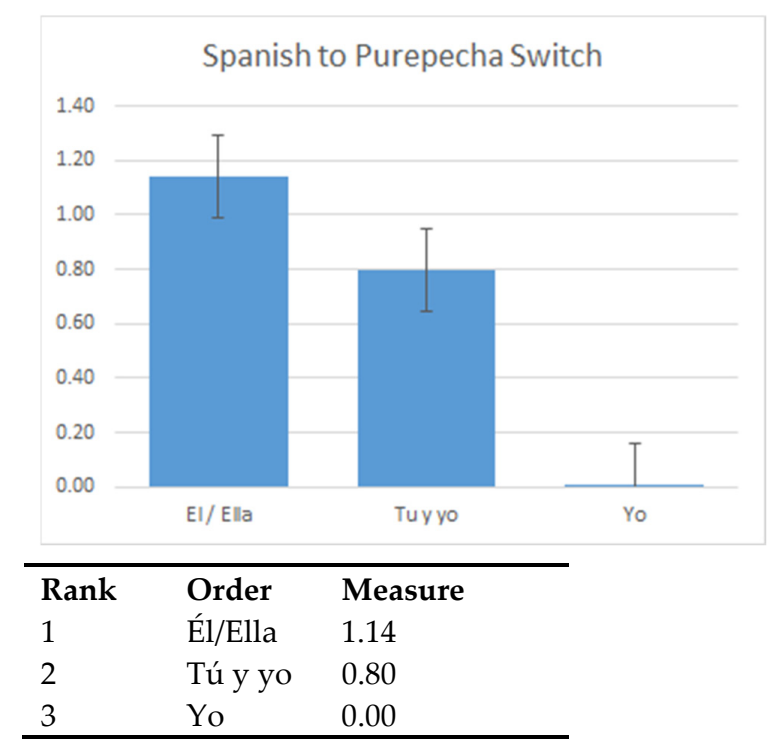

Figure 1. Rank ordering of $2 \mathrm{AFC}$ results for Spanish to P'urhepecha switches (above), including the measure of Thurstone's analysis (below). 


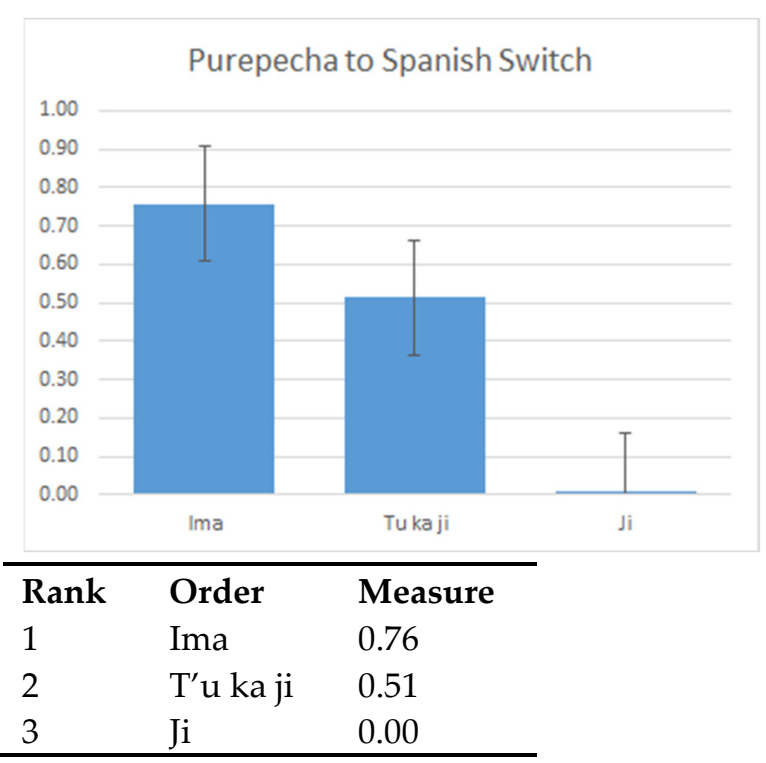

Figure 2. Rank ordering of $2 \mathrm{AFC}$ results for P'urhepecha to Spanish switches (above), including the measure of Thurstone's analysis (below).

While the rank ordering is the same for $\mathrm{P}^{\prime}$ urhepecha to Spanish switches, only the difference between 1SG and the other two conditions (1PL coordinated and 3SG) is significant (see Figure 2). The difference between 3SG and 1PL coordinated conditions approaches significance and, in all likelihood, this difference would become significant with a few more participants. ${ }^{2}$

These results are rather unexpected. Following, inter alia, González-Vilbazo and Koronkiewicz (2016), we would expect the coordinated 1PL pronoun in Spanish to be more acceptable than the weak 3SG or 1SG, but this is not what we find. Indeed, despite Spanish él/ella 's/he' being weak pronouns/system morphemes, and P'urhepecha ima 's/he' a strong pronoun/content morpheme, both are the most acceptable choice for the participants.

\section{Discussion and Conclusions}

The main finding of the present study is that code-switches involving a 3SG pronoun and a finite verb were considered the most accepted for both switch directions, followed by coordinated 1PL, and then 1SG. On the basis of previous studies, we predicted that coordinated pronouns would be more acceptable in switches than non-coordinated pronouns (RQ1). This prediction was clearly not borne out by the findings. That 3SG is acceptable in both directions also contrasts with MacSwan's (1999) judgement findings for Spanish-Nahuatl, where the 3SG pronoun was only accepted when it occurred in Spanish We could therefore view the present results as an example of language-specific patterns in code-switching, since a universal ordering cannot be sustained. In the absence of results from another P'urhepecha-Spanish bilingual community, it is perhaps unwise to claim that the patterns are also community-specific. Nevertheless, it seems clear that previous claims regarding the acceptability of pronoun-verb switches should be revised in light of these new data.

We also predicted that third person pronouns in P'urhepecha would be preferred as they could be considered content morphemes, while the other pronouns (and all those in Spanish) could be considered system morphemes and thus dispreferred (RQ2). In Minimalist/generativist terms, the lexically strong 3SG in P'urhepecha would be preferred over the other, lexically weak pronouns. This prediction was partially upheld, since 3SG was the preferred pronoun for switches, but both strong (i.e., $\mathrm{P}^{\prime}$ urhepecha ima 's/he') and weak (i.e., Spanish él 'he') behaved identically, contrary to predictions.

However, this result is not necessarily that surprising, given the results of previous studies. Parafita Couto and Stadthagen-Gonzalez (2019), for example, find that the norms of 
the Spanish-English bilingual community under investigation were to express no preference for a particular switch direction in mixed NPs. This lack of preference is observed in two types of judgement tasks (forced-choice and Likert scale), despite naturalistic production data in the same language pair showing far more switches from Spanish to English, i.e., that Spanish functions overwhelmingly as the Matrix Language. We could view this as a difference between receptive and productive language.

A similar situation seems to hold for P'urhepecha-Spanish: in a corpus of around ten hours (Bellamy forthcoming), P'urhepecha is overwhelmingly the Matrix Language in code-switched speech (although it should be highlighted that this may not be true of all P'urhepecha-Spanish-speaking communities). Given the attested directionality preference in production, we might therefore expect speakers to have less clear judgements in their less frequent switch direction and, thus, follow the judgements they would make for switches in the more frequent direction. A similar finding emerged from an acceptability judgement task measured with event-related potentials (ERP): Vaughan-Evans et al. (2020) found that Welsh-English bilinguals only differentiated between adherence and violation conditions when the matrix language of the stimulus was Welsh, i.e., for Welsh to English code-switches.

That said, it is acknowledged that despite their richness and ecological validity, corpus data are not exhaustive, and not all naturally occurring structures will appear in a given corpus, irrespective of its size. Moreover, corpora are not probative in nature, but rather can be used to generate hypotheses and construct experimental materials (StadthagenGonzález et al. 2018). As we saw above, it is possible for receptive and productive language to not fully overlap (yet both being part of a person's language competence), and for those differences to be reflected in specific tasks. Consequently, judgement tasks provide a valuable means of testing - and potentially falsifying - these generated hypotheses in a controlled, more probative, way than could be accomplished with corpus-based research alone. As also indicated above, the forced-choice format also has advantages over scaled or yes/no judgement tasks, since the latter are more likely to be affected by extra-linguistic factors such as attitudes and also display weaker intra- and inter-participant reliability (see, e.g., Párraga (2015)). Indeed, this study also highlights the benefit of using a 2AFC judgement task: despite the wide range of attitudes towards code-switching reported by the participants (see Section 3), the results are very clear.

In sum, the findings of the present study indicate that the patterns of subject pronounfinite verb code-switches vary between language pairs, rather than constituting universal constraints of code-switching behaviour. More data from this and other communities is necessary to expand our understanding of the limits of this particular code-switch, amongst many others. Code-switched language reveals combinatorial possibilities that would otherwise be hidden in monolingual speech, and so is vital for refining grammatical theory (see Vanden Wyngaerd (2021) for an overview). In addition, the results highlight both the advantage and the need for data to be collected using multiple methods (see also Parafita Couto et al. (2021); Gullberg et al. (2009)). More extensive, comparable data will help us to tease apart the relationship between acceptability and usage patterns. The ultimate goal of such work, therefore, is to test and refine existing models of code-switching in order to improve our understanding of (multilingual) language competence.

Author Contributions: Conceptualisation, K.B., H.S.-G., M.C.P.C.; methodology, M.C.P.C., H.S.-G.; formal analysis, H.S.-G.; writing—original draft preparation, K.B., H.S.-G., M.C.P.C.; writing—review and editing, H.S.-G., M.C.P.C., K.B.; visualization, H.S.-G. All authors have read and agreed to the published version of the manuscript.

Funding: During the writing of this article, Kate Bellamy was funded by a Marie Curie Individual Fellowship, grant number 845430 , and in the revision phase by a Postdoctoral Mandate at KU Leuven.

Informed Consent Statement: Informed consent was obtained from all subjects involved in the study.

Data Availability Statement: While the stimuli and overall responses are reported in this paper, the full dataset underpinning this study can be obtained from the authors. 
Conflicts of Interest: The authors declare no conflict of interest.

\section{Appendix A}

Table A1. Experimental stimuli: Spanish to P'urhepecha switches.

\begin{tabular}{|c|c|c|c|}
\hline StimID & Item & Contrast & Spanish Translation \\
\hline $1 \mathrm{a}$ & yo wani anchikurixïnkani & 1SG & trabajo mucho \\
\hline $1 b$ & él/ella wani anchikurixïnti & 3SG & trabaja mucho \\
\hline $2 \mathrm{a}$ & yo churikwa kw'ixïnkani & 1SG & duermo (durante) la noche \\
\hline $2 b$ & él/ella churikwa kw'ixïnti & 3SG & duerme (durante) la noche \\
\hline $3 a$ & yo kokani jamaxïnkani & 1SG & camino rapidamente \\
\hline $3 b$ & él/ella kokani jamaxïnti & 3SG & camina rapidamente \\
\hline $4 \mathrm{a}$ & yo winani pirixïnkani & 1SG & canto alto \\
\hline $4 b$ & él/ella winani pirixïnti & 3SG & canta alto \\
\hline $5 a$ & yo wekaxïnkani warhani & 1SG & quiero bailar \\
\hline $5 b$ & él/ella wekaxïnti warhani & 3SG & quiere bailar \\
\hline $6 a$ & yo wetarhikani erokani & 1SG & debo esperar \\
\hline $6 b$ & él/ella wetarhiti erokani & 3SG & debe esperar \\
\hline $7 \mathrm{a}$ & yo yot'akwa anchikurixïnkani & 1SG & trabajo (hasta) tarde \\
\hline $7 \mathrm{~b}$ & tu y yo yot'akwa anchikurixïnkakxï & $1 \mathrm{PL}$ & trabajamos (hasta) tarde \\
\hline $8 \mathrm{a}$ & yo kant'arxku kw'ixïnkani & 1SG & duermo cuando sea \\
\hline $8 b$ & tu y yo kant'arxku kw'ixïnkakxï & 1PL & dormimos cuando sea \\
\hline $9 \mathrm{a}$ & yo yapuru jamaxïnkani & 1SG & camino dondequiera \\
\hline $9 b$ & tu y yo yapuru jamaxïnkakxï & 1PL & caminos dondequiera \\
\hline $10 \mathrm{a}$ & yo sani pirixïnkani & 1SG & canto poco \\
\hline $10 b$ & tu y yo sani pirixïnkakxï & $1 P L$ & cantamos poco \\
\hline $11 \mathrm{a}$ & yo wekaxïnkani karani & 1SG & quiero escribir \\
\hline $11 b$ & tu y yo wekaxïnkakxï karani & $1 P L$ & queremos escribir \\
\hline $12 \mathrm{a}$ & yo niakani tianguisrhu & 1SG & iré al mercado/tianguis \\
\hline $12 b$ & tu y yo niakakxï tianguisrhu & $1 \mathrm{PL}$ & iremos al mercado/tianguis \\
\hline $13 a$ & él/ella mantani jurhiatani anchikurixïnti & 3SG & trabaja cada día \\
\hline $13 b$ & tu y yo mantani jurhiatani anchikurixïnkakxï & 1PL & trabajamos cada día \\
\hline $14 \mathrm{a}$ & él/ella inchatiru kw'ixïnti & 3SG & duerme (hasta) tarde \\
\hline $14 b$ & tu y yo inchatiru kw'ixïnkakxï & 1PL & dormemos (hasta) tarde \\
\hline $15 \mathrm{a}$ & él/ella niati tarhu & 3SG & irá a casa \\
\hline $15 b$ & tu y yo niakakxï tarhu & 1PL & iremos a casa \\
\hline $16 \mathrm{a}$ & él/ella piriti pirekwaecha & 3SG & canta canciones tradicionales \\
\hline $16 b$ & tu y yo pirikakxï pirekwaecha & 1PL & cantemos canciones tradicionales \\
\hline $17 \mathrm{a}$ & él/ella wekaxïnti ninirani & 3SG & quiere cocinar \\
\hline $17 \mathrm{~b}$ & tu y yo wekaxïnkakxï ninirani & 1PL & queremos cocinar \\
\hline $18 \mathrm{a}$ & él/ella wetarhiti t'ireni kupandaechani & 3SG & debe comer aguacates \\
\hline $18 b$ & tu y yo wetarhikakxï t'ireni kupandaechani & $1 P L$ & debemos comer aguacates \\
\hline
\end{tabular}

Table A2. Experimental stimuli: P'urhepecha to Spanish switches. Note that the translations are the same as for the target items presented in the table above.

\begin{tabular}{|c|c|c|}
\hline StimID & Item & Contrast \\
\hline $1 \mathrm{a}$ & ji trabajo cada día hasta a las 10 & $1 S G$ \\
\hline $1 b$ & ima trabaja cada día hasta a las 10 & 3SG \\
\hline $2 \mathrm{a}$ & ji duermo durante el día & 1SG \\
\hline $2 b$ & ima duerme durante el día & 3SG \\
\hline $3 a$ & ji camino rapidamente & $1 S G$ \\
\hline $3 b$ & ima camina rapidamente & 3SG \\
\hline $4 \mathrm{a}$ & ji canto demasiado alto & 1SG \\
\hline $4 b$ & ima canta demasiado alto & 3SG \\
\hline $5 \mathrm{a}$ & ji quiero bailar bachata & $1 S G$ \\
\hline $5 b$ & ima quiere bailar bachata & 3SG \\
\hline $6 a$ & ji debo esperar el autobús & 1SG \\
\hline $6 b$ & ima debe esperar el autobús & 3SG \\
\hline $7 \mathrm{a}$ & ji trabajo en una escuela primaria & $1 S G$ \\
\hline $7 \mathrm{~b}$ & $t^{\prime} u$ ka ji trabajamos en una escuela primaria & $1 \mathrm{PL}$ \\
\hline $8 \mathrm{a}$ & ji vivo en Santa Fe de la Laguna & $1 S G$ \\
\hline $8 b$ & $t^{\prime}$ u ka ji vivimos en Santa Fe de la Laguna & 1PL \\
\hline
\end{tabular}


Table A2. Cont.

\begin{tabular}{|c|c|c|}
\hline StimID & Item & Contrast \\
\hline $9 \mathrm{a}$ & ji corro muy lentamente & $1 S G$ \\
\hline $9 b$ & $\mathrm{t}^{\prime} \mathrm{u}$ ka ji corremos muy lentamente & 1PL \\
\hline $10 \mathrm{a}$ & ji hablo con la vecina en la mañana & 1SG \\
\hline $10 \mathrm{~b}$ & $t^{\prime} u$ ka ji hablamos con la vecina en la mañana & 1PL \\
\hline $11 \mathrm{a}$ & ji quiero pintar los muros de la casa & $1 S G$ \\
\hline $11 b$ & $\mathrm{t}^{\prime} \mathrm{u}$ ka ji queremos pintar los muros de la casa & 1PL \\
\hline $12 \mathrm{a}$ & ji debo ir a la tienda & 1SG \\
\hline $12 b$ & $\mathrm{t}^{\prime} \mathrm{u}$ ka ji debemos ir a la tienda & 1PL \\
\hline $13 a$ & ima trabaja cada fin de semana & 3SG \\
\hline $13 b$ & $t^{\prime} \mathrm{u}$ ka ji trabajamos cada fin de semana & 1PL \\
\hline $14 \mathrm{a}$ & ima duerme hasta tarde la mañana & 3SG \\
\hline $14 b$ & t'u ka ji dormemos hasta tarde la mañana & 1PL \\
\hline $15 \mathrm{a}$ & ima camina muy rapidamente & 3SG \\
\hline $15 b$ & $\mathrm{t}^{\prime} \mathrm{u}$ ka ji caminamos muy rapidamente & 1PL \\
\hline $16 \mathrm{a}$ & ima canta canciones tradicionales & 3SG \\
\hline $16 b$ & t’u ka ji cantemos canciones tradicionales & 1PL \\
\hline $17 \mathrm{a}$ & ima quiere cocinar un plato frances & 3SG \\
\hline $17 \mathrm{~b}$ & $\mathrm{t}^{\prime} \mathrm{u}$ ka ji queremos cocinar un plato frances & 1PL \\
\hline $18 \mathrm{a}$ & ima debe comer galletas cada día & 3SG \\
\hline $18 b$ & t’u ka ji debemos comer galletas cada día & 1PL \\
\hline
\end{tabular}

\section{Notes}

1 The following abbreviations are used in this paper: 1 first person, 2 second person, 3 third person, ASS assertive, FUT future, INTERROG interrogative, 3 third person, NSF absolutive, $\mathrm{O}$ object, PERF perfective, PL plural, PRED predicativisor, $\mathrm{S}$ subject, $\mathrm{s}$ singular object, SF stem formative, SG singular.

2 While we acknowledge that a larger sample could have made certain marginal differences significant, obtaining more participants proved very difficult.

\section{References}

Bellamy, Kate, M. Carmen Parafita Couto, and Hans Stadthagen-Gonzalez. 2018. Investigating Gender Assignment Strategies in Mixed P'urhepecha-Spanish Nominal Constructions. Languages 3: 28. [CrossRef]

Bellamy, Kate. 2018. On the External Relations of Purepecha: An Investigation into Classification, Contact and Patterns of Word Formation. Ph.D. dissertation, Leiden University, Leiden, The Netherlands.

Bellamy, Kate. forthcoming. P'urhepecha Texts, FLEx corpus. (Latest version available on request).

Bentahila, Abdelâli, and Eirlys E. Davies. 1983. The syntax of Arabic-French code-switching. Lingua 59: 301-30. [CrossRef]

Blokzijl, Jeffrey, Margaret Deuchar, and M. Carmen Parafita Couto. 2017. Determiner Asymmetry in Mixed Nominal Constructions: The Role of Grammatical Factors in Data from Miami and Nicaragua. Languages 2: 20. [CrossRef]

Capistrán Garza, Alejandra. 2015. Multiple Object Constructions in P'orhépecha: Argument Realization and Valence-Affecting Morphology. Leiden and Boston: Brill.

Cardinaletti, Anna, and Michal Starke. 1999. The typology of structural deficiency: A case study of the three classes of pronouns. In Clitics in the Languages of Europe. Edited by Henk van Riemsdijk. Berlin: De Gruyter, pp. 145-233.

Chamoreau, Claudine. 2000. Grammaire du Purépecha, parlé sur les îles de Patzcuaro. Munich: LINCOM EUROPA.

Deuchar, Margaret. 2012. Code-switching. In Encyclopedia of Applied Linguistics. Edited by Carol Chapelle. New York: Wiley, pp. 657-64.

Deuchar, Margaret. 2020. Code-Switching in Linguistics: A Position Paper. Languages 5: 22. [CrossRef]

Foster, Mary Le Cron. 1969. The Tarascan Language. Berkeley: University of California Press.

Friedrich, Paul. 1971. The Tarascan Suffixes of Locative Space. Bloomington: Indiana University Press.

Friedrich, Paul. 1984. Tarascan: From Meaning to Sound. In Supplement to the Handbook of Middle American Indians, Volume 2: Linguistics. Edited by Munro S. Edmonson. Austin: University of Texas Press, pp. 56-82.

Fuertes, Raquel Fernández, Juana M. Liceras, and Anahí Alba de la Fuente. 2016. Beyond the subject DP versus the subject pronoun divide in agreement switches. In Romance Linguistics 2013. Selected Papers from the 43rd Linguistic Symposium on Romance Languages (LSRL), New York, NY, USA, April 17-19. Edited by Christina Tortora, Marcel den Dikken, Ignacio L. Montoya and Teresa O'Neill. Amsterdam and Philadelphia: John Benjamins, pp. 79-98.

Gilberti, Maturino. 1975. Diccionario de la lengua Tarasca o de Michoacan; edición facsimilas, con nota preliminar de José Corona Nuñez. Morelia: Balsal. First published 1559.

Gilberti, Maturino. 1987. Arte de la lengua de Michuacan. México: Fimax Publicistas Editoras. First published 1558. 
González-Vilbazo, Kay, and Bryan Koronkiewicz. 2016. Tú y yo can codeswitch, nosotros cannot: Pronouns in Spanish-English codeswitching. In Spanish-English Codeswitching in the Caribbean and the US. Edited by Rosa E. Guzzardo Tamargo, Catherine M. Mazak and M. Carmen Parafita Couto. Amsterdam: John Benjamins, pp. 237-60.

Gullberg, Marianne, Peter Indefrey, and Pieter Muysken. 2009. Research techniques for the study of codeswitching. In The Cambridge Handbook of Linguistic Code-Switching. Edited by Barbara E. Bullock and Almeida Jacqueline Toribio. Cambridge: Cambridge University Press, pp. 21-39.

INEGI. 2010. Población de 5 años y más que habla lengua indígena y no habla español por principales lenguas según sexo, 2000 y 2010. In Censos de Población y Vivienda, 2000 y 2010. México: INEGI.

Jake, Janice L. 1994. Intrasentential code switching and pronouns: On the categorial status of functional elements. Linguistics 32: 271-98. [CrossRef]

Johns, Michael A., and Jonathan Steuck. 2021. Is codeswitching easy or difficult? Testing processing cost through the prosodic structure of bilingual speech. Cognition 211: 104634. [CrossRef] [PubMed]

Koronkiewicz, Bryan. 2020. Subject-predicate code-switching: Testing the need of a matrix language through embedding. In Hispanic Linguistics: Current Issues and New Directions. Edited by Alfonso Morales-Front, Michael J. Ferreira, Ronald P. Leow and Cristina Sanz. Amsterdam and Philadelphia: John Benjamins, pp. 250-64.

Labov, William. 1971. The notion of 'system' in creole studies. In Pidginization and Creolization of Languages. Edited by D. Hymes. Cambridge: Cambridge University Press, pp. 447-72.

Lipski, John M. 1978. Code-switching and the problem of bilingual competence. In Aspects of Bilingualism. Edited by M. Paradis. Columbia: Hornbeam Press, pp. 250-64.

Lipski, John M. 2019. Field-Testing Code-Switching Constraints: A Report on a Strategic Languages Project. Languages 4: 7. [CrossRef] López, Luis. 2020. Bilingual Grammar: Toward an Integrated Model. Cambridge: Cambridge University Press.

MacSwan, Jeff. 1999. A Minimalist Approach to Intrasentential Code Switching. New York: Garland.

MacSwan, Jeff. 2021. Theoretical approaches to the grammar of code-switching. In The Routledge Handbook of Language Contact. Edited by Evangelia Adamou and Yaron Matras. Oxford and New York: Routledge, pp. 88-109.

Mendoza, Martha. 2007. Derivational Resources in P'urhepecha: Morphological Complexity and Verb Formation. Acta Linguistica Hungarica 54: 157-72. [CrossRef]

Meuter, Renata F., and Alan Allport. 1999. Bilingual language switching in naming: Asymmetrical costs of language selection. Journal of Memory and Language 40: 25-40. [CrossRef]

Miccio, Adele W., Carol Scheffner Hammer, and Bárbara Rodríguez. 2009. Code-switching and language disorders in bilingual children. In The Cambridge Handbook of Linguistic Code-Switching. Edited by Barbara E. Bullock and Almeida Jacqueline Ed Toribio. Cambridge: Cambridge University Press, pp. 241-52.

Mohan, B. A. 1977. Acceptability testing and fuzzy grammar. In Acceptability in Language. Edited by Sidney Greenbaum. The Hague: Mouton, pp. 133-48.

Montag, Ethan D. 2006. Empirical formula for creating error bars for the method of paired comparisons. Journal of Electronic Imaging 15: $222-30$.

Monzón, Cristina. 2004. Los Morfemas Espaciales del p'urhépecha. Zamora: El Colegio de Michoacán.

Myers-Scotton, Carol. 1993. Social Motivations for Codeswitching: Evidence from Africa. Oxford: Oxford University Press.

Myers-Scotton, Carol. 2002. Contact Linguistics: Bilingual Encounters and Grammatical Outcomes. Oxford: Oxford University Press. [CrossRef]

Parafita Couto, M. Carmen, and Hans Stadthagen-Gonzalez. 2019. El book or the libro? Insights from acceptability judgments into determiner/noun code-switches. International Journal of Bilingualism 23: 349-60. [CrossRef]

Parafita Couto, M. Carmen, Miriam Greidanus Romaneli, and Kate Bellamy. 2021. Code-switching at the interface between language, culture, and cognition. Lapurdum. Available online: https://halshs.archives-ouvertes.fr/halshs-03280922/ (accessed on 8 August 2021).

Párraga, C. Alejandro. 2015. Perceptual Psychophysics. In Biologically-Inspired Computer Vision: Fundamentals and Applications. Edited by Gabriel Cristobal, Matthias S. Keil and Laurent Perrinet. New York: Wiley, pp. 81-108.

Poplack, Shana. 1980. Sometimes I'll start a sentence in Spanish y termino en español: Toward a typology of code-switching. Linguistics 18: 581-618. [CrossRef]

Sprouse, Jon. 2011. Continuous acceptability, categorical grammaticality, and experimental syntax. Biolinguistics 1: 118-29. [CrossRef]

Stadthagen-González, Hans, Luis López, M. Carmen Parafita Couto, and C. Alejandro Párraga. 2018. Using two-alternative forced choice tasks and Thurstone's law of comparative judgments for code-switching research. Linguistic Approaches to Bilingualism 8: 67-97. [CrossRef]

Thurstone, Louis L. 1927. A law of comparative judgment. Psychological Review 34: 273-86. [CrossRef]

Timm, Lenora A. 1975. Spanish-English code-switching: El porque and how-not-to. Romance Philology 28: 473-82.

Toribio, Almeida Jacqueline. 2017. Structural approaches to code-switching: Research then and now. In Romance Languages and Linguistic Theory 12: Selected Papers from the 45th Linguistic Symposium on Romance Languages (LSRL), Campinas, Brazil. Edited by Ruth E. V. López, Juanito Ornelas de Avelar and Sonia M. L. Cyrino. Amsterdam: John Benjamins Publishing Company, pp. 213-33. 
van Gelderen, Elly, and Jeff MacSwan. 2008. Interface conditions and code-switching: Pronouns, lexical DPs, and checking theory. Lingua 118: 765-76. [CrossRef]

Vanden Wyngaerd, Emma. 2021. Bilingual Implications: Using Code-Switching Data to Inform Linguistic Theory. Ph.D. dissertation, Université Libre de Bruxelles, Brussels, Belgium.

Vaughan-Evans, Awel, M. Carmen Parafita Couto, Bastien Boutonnet, Noriko Hoshino, Peredur Webb-Davies, Margaret Deuchar, and Guillaume Thierry. 2020. Switchmate! An Electrophysiological Attempt to Adjudicate Between Competing Accounts of Adjective-Noun Code-Switching. Frontiers in Psychology 11: 2341. [CrossRef] [PubMed] 